\title{
THE EFFECT OF HARVESTING DATES ON SOME AGRONOMIC AND QUALITY CHARACTERISTICS OF PEANUT (Arachis hypogaea L.) VARIETIES GROWN AS A MAIN CROP IN MEDITERRANEAN REGION (TURKEY)
}

\author{
Halis ARIOGLU ${ }^{1^{*}}$, Halil BAKAL ${ }^{1}$, Leyla GULLUOGLU ${ }^{1}$, Bihter ONAT ${ }^{2}$, Cemal KURT \\ ${ }^{1}$ Cukurova University, Faculty of Agriculture, Department of Field Crops, Adana, TURKEY \\ ${ }^{2}$ Cukurova University, Vocational School of Kozan, Adana, TURKEY \\ *Corresponding author: halis@cu.edu.tr \\ **Some of the data belonging to 2015 year were used in two different International Symposiums.
}

Received: 07.02.2018

\begin{abstract}
This study was conducted at the experimental area of the Department of Field Crops, Faculty of Agriculture, Cukurova University as a main crop in 2015 and 2016. The objective of this study was to determinate the effect of harvesting dates on some agronomic and quality characteristics of peanut (Arachis hypogaea L.) varieties grown as a main crop in Mediterranean region (Turkey). The experimental design was a split plot with three replications. The Halisbey, Sultan, Arioglu-2003, Osmaniye-2005, NC-7, Batem-5025, Flower-22, Flower-32, Flower-36, Brantley and Wilson peanut varieties (Virginia market type) were used as a plant material in this research. The plants were harvested at 149, 156, 163 and 170 days after sowing (DAS).

In this research; the pod yield per hectare, shelling percentage, 100-seed weight, maturity index, pod number per plant, pod weight per plant, protein and oil percentage characteristics and fatty acids composition of varieties were investigated. The results indicated that the pod yield per hectare, shelling percentage, 100-seed weight, maturity index, pod number per plant, pod weight per plant, oil percentage, stearic and oleic acids percentage values were increased when the harvesting delayed, but the protein content, palmitic and linoleic acids percentage were decreased.The pod yield was increased from $4185 \mathrm{kgha}^{-1}$ to $5682 \mathrm{kgha}^{-1}$ when the harvesting delayed from 149 DAS to 170 DAS in a two year average.
\end{abstract}

Key Words: Fatty acid, Harvesting time, Oil content, Peanut, Pod yield

\section{INTRODUCTION}

Peanut seeds contain $35-56 \%$ oil and $25-30 \%$ protein and $9.5-19.0 \%$ carbohydrate. In addition, they are a good source of mineral and vitamins. For this reason, it is an important source of edible oil and protein for human nutrition (Gulluoglu 2011; Arioglu et al., 2013; Chamberlin et al., 2014 and Chowdhury et al., 2015). Peanut (Arachis hypogaea L.) is an important oilseed crop for vegetable oil production. It contributes $8.7 \%$ of the total oil seeds production in the world. Peanut oil accounted for $3.0 \%$ of the world's vegetable oil production in 2015 (FAO, 2015).

Ishag (2000), Jordan et al. (2008) and Kaba et al. (2014) reported that peanut has indeterminate growth habit and the plants produced many flowers during the growing period,but only $15-20 \%$ of flowers produced mature pods.Young et al. (1982) reported that total pod production continually increased with growth period, but that harvested yield reached a peak and then declined due to increased field losses at delayed the harvesting date.

Court et al. (1984) and Gulluoglu et al. (2016a) found that delayed digging increased yield, sound mature kernels, shelling percentage and oil content. Sattayarak (1997) pointed out that harvesting dates exhibited certain effects on yield, 100-seed weight, shelling percentage, oil and protein contents in peanut. Canavar and Kaynak (2013) reported that, pod number and pod yield per plant, 100-seed weight, shelling percentage, pod yield, oil and protein content were increased by delaying the harvesting time.

Lu et al. (1997) reported that the lowest pod and seed yield, oil and protein content were found in the earliest harvested peanuts. Wright and Porter (1991) and Kaba et al. (2014) indicated that harvesting peanut too early reduced yield by $15 \%$ and economic value by $21 \%$. Therefore, it is very important to harvest the peanut plant 
at an appropriate time in order to get high yield and reduce yield losses.

Oil content is an important quality characteristic in peanut seed. The oil content of peanut seed influences by genotypic variation, growing conditions and maturity. The oil content of peanut varieties was increased by delaying the harvesting times (Lu et al., 1997 and Canavar and Kaynak, 2013). Young and Worthington (1974), Dwivedi et al. (1996) and Isleib et al. (2008) reported that fatty acid composition of peanut seed oil influenced by varietal and seasonal variation, genotypic variation, air and soil temperature, planting date, soil nutrient, growing conditions and maturity.

Andersen and Gorbet (2002) and Gulluoglu et al. (2016a) reported that, seed maturity can also influence the fatty acid composition of peanut. In general, oleic acid increases and linoleic acid decrease with seed maturity. The increase in oleic acid with seed maturity is normally accompanied by a decrease in palmitic and linoleic acids. Bovi (1982), Raheja et al. (1987) and Onemli (2012) reported that there was a negative correlation between oleic acid and linoleic acid.

Peanut has been grown as a main and double cropped after a small grain harvest in the Cukurova region in Turkey. Fatty acid composition of peanut is not constant. The fatty acid composition of peanut oil varies depending on varieties, growing conditions and maturity.The objective of the study is to investigate the effect of harvesting times on agronomic and quality traits of peanut varieties grown as a main crop in Mediterranean Region of Turkey.

\section{MATERIALS AND METHODS}

\section{Materials}

This experiment was conducted in 2015 and 2016 at Research Farm of Cukurova University (Southern Turkey, $36^{\circ} 59^{\mathrm{l}} \mathrm{N}, 35^{\circ} 18^{1} \mathrm{E}$ and $23 \mathrm{~m}$ elevation) as a main crop. Halisbey, Sultan, Arioglu-2003, Osmaniye-2005, NC-7, Batem-5025, Flower-22, Flower-32, Flower-36, Brantley and Wilson peanut varieties belonging to Virginia market type were used as a plant material in this research.

The soil texture was clay loam. The soil tests indicated that $\mathrm{pH}$ of 7.5 with high concentrations of $\mathrm{K}_{2} \mathrm{O}$ and low concentrations of $\mathrm{P}_{2} \mathrm{O}_{5}$. In addition, the organic matter and nitrogen content of the soil were very low. The lime content was $20.5 \%$ in the upper layers with increased levels in lower layers.

This study was conducted in Adana province in Turkey and in this region, winters are mild and rainy, whereas summers are dry and warm, which is a typical of a Mediterranean climate.The climate data during the 2015-2016 growing period and long term (LT) average (1982-2015) was shown in Table 1.

Table 1. The climate conditions during the 2015-2016 growing period and long term (LT) average (1982-2015) (Anonymous, 2017)

\begin{tabular}{lccccccccc}
\hline \multirow{2}{*}{ Months } & \multicolumn{3}{c}{ Average temperature $\left({ }^{\circ} \mathbf{C}\right)$} & \multicolumn{3}{c}{ Precipitation $(\mathbf{m m})$} & \multicolumn{3}{c}{ Relative humidity $(\%)$} \\
\cline { 2 - 9 } & $\mathbf{2 0 1 5}$ & $\mathbf{2 0 1 6}$ & $\mathbf{L T}$ & $\mathbf{2 0 1 5}$ & $\mathbf{2 0 1 6}$ & LT & $\mathbf{2 0 1 5}$ & $\mathbf{2 0 1 6}$ & LT \\
\hline April & 16.9 & 20.5 & 17.3 & 21.5 & 36.6 & 48.6 & 61.2 & 59.2 & 67.6 \\
May & 22.5 & 21.6 & 21.4 & 65.7 & 87.9 & 41.2 & 64.8 & 69.3 & 67.3 \\
June & 25.0 & 27.1 & 25.2 & 4.8 & 45.6 & 14.5 & 69.6 & 66.1 & 67.9 \\
July & 28.4 & 29.5 & 27.8 & 0.4 & 0.2 & 7.9 & 69.8 & 67.5 & 71.4 \\
August & 30.0 & 29.9 & 28.4 & 10.9 & 8.2 & 6.1 & 63.4 & 69.0 & 70.8 \\
September & 28.4 & 26.3 & 25.1 & 13.1 & 39.8 & 15.7 & 64.8 & 61.8 & 63.2 \\
October & 23.4 & 23.1 & 20.6 & 32.1 & 0.0 & 45.7 & 63.7 & 56.4 & 59.5 \\
\hline
\end{tabular}

\section{Methods}

The experiment was designed as a split plot design (harvesting times as main plots and varieties as subplots) with three replications. $250 \mathrm{kgha}^{-1}$ of Di-ammonium phosphate $\left(45 \mathrm{kgha}^{-1} \mathrm{~N}, 115 \mathrm{kgha}^{-1} \mathrm{P}_{2} \mathrm{O}_{5}\right.$ ) fertilizer was applied and incorporated to soil before planting. Ammonium nitrate $(33 \% \mathrm{~N})$ at the rates of $200 \mathrm{kgha}^{-1}$ was applied two times; before first (beginning of flowering) and second (pod formation) irrigation in each years. Individual plots consisted of 4 rows $5.0 \mathrm{~m}$ long and $70 \mathrm{~cm}$ apart. The seeds were sown in line manually by hand on first week of April (5 April) and with 70x15 cm distance in a two year. During the growing period, recommended pesticides and fungicides were applied to control insects and diseases. The remaining cultural practices were applied during the growing period. The plants were harvested by hand at four different times with one week intervals (149 DAS, 156 DAS, 163 DAS and 170 DAS) at the beginning of September in 2015 and 2016.

Data collection and analysis: Data on agronomic and quality characteristics like pod number and pod weight per plant, maturity index, shelling percentage, 100-seed weight, pod yield per hectare,oil and protein content and fatty acids (palmitic, stearic, oleic and linoleic) content were recorded in a each harvesting time with seven days intervals (Gulluoglu et al., 2016b; AOCS, 2010 and William and Drexler, 1981).

The collected data on different parameters were statistically analyzed to obtain the level of significance using JUMP 8.1.0 package program with split plot design. The means differences were compared with the Least Significant Differences (LSD, 5\%) Test. 


\section{RESULTS AND DISCUSSIONS}

\section{Pod number and pod weight}

The average data belonging to pod number and pod weight per plant values of peanut varieties at different harvesting times has been presented in Table 2.

As it can be seen in Table 2, The differences between the harvesting times for the pod number per plant were statistically significant in 2015, 2016 and two years average.Pod number per plant values varied between 15.9 and 21.0 pods plant ${ }^{-1}$ in 2015 , between 15.7 and 21.0 pods plant $^{-1}$ in 2016. The pod number was increased when the harvesting delayed from 149 DAS to 170 DAS in both years. While the pod number per plant $^{-1}$ was 15.8 pods plant $^{-1}$ when the plants harvested at the 149 DAP, it was increased to 21.0 pods plant $^{-1}$ plants harvested at the 170 DAP in a two-year average. Peanut has indeterminate growth habit and the plants produce flowers and pods as a long timeduring the growing period. For this reason,the pod number was increased when the harvesting delayed. Young et al. (1982) and Canavar and Kaynak (2013) reported that, pod number per plant was increased by delaying the harvesting time. Gulluoglu et al. (2016a) found that according to a two-year average the highest pod number per plant $\left(38.83\right.$ pods plant $\left.^{-1}\right)$ was obtained when the plants were harvested at 180 DAP in Mediterranean region.

Table 2. Effects of harvesting times on pod number and pod weight values of peanut varieties

\begin{tabular}{|c|c|c|c|c|c|c|}
\hline \multirow{2}{*}{ Treatments } & \multicolumn{3}{|c|}{ Pod number (pods plant $\left.{ }^{-1}\right)$} & \multicolumn{3}{|c|}{ Pod weight $\left(\right.$ g plant $\left.^{-1}\right)$} \\
\hline & 2015 & 2016 & $2015-2016$ & 2015 & 2016 & $2015-2016$ \\
\hline \multicolumn{7}{|c|}{ Harvesting times (A) } \\
\hline $149 \mathrm{DAS}$ & 15.9 & 15.7 & 15.8 & 39.3 & 40.5 & 39.9 \\
\hline 156 DAS & 18.2 & 18.6 & 18.4 & 47.0 & 45.8 & 46.4 \\
\hline $163 \mathrm{DAS}$ & 19.4 & 19.8 & 19.6 & 52.5 & 51.5 & 52.0 \\
\hline 170 DAS & 21.0 & 21.0 & 21.0 & 57.5 & 55.9 & 56.7 \\
\hline $\operatorname{LSD}\left(\% 5_{\mathrm{A}}\right)$ & 1.14 & 1.10 & 2.45 & 3.86 & 1.99 & 8.32 \\
\hline \multicolumn{7}{|l|}{ Varieties (B) } \\
\hline Halisbey & 21.9 & 21.1 & 22.0 & 61.4 & 63.0 & 62.2 \\
\hline Sultan & 25.8 & 25.3 & 25.6 & 75.8 & 73.7 & 74.7 \\
\hline Arioglu-2003 & 22.1 & 21.7 & 21.9 & 49.0 & 47.7 & 48.4 \\
\hline Osmaniye-2005 & 26.4 & 27.0 & 26.7 & 70.2 & 72.7 & 71.4 \\
\hline $\mathrm{NC}-7$ & 13.5 & 13.9 & 13.7 & 33.2 & 33.6 & 33.9 \\
\hline Batem-5025 & 15.0 & 15.2 & 15.1 & 40.9 & 38.0 & 39.5 \\
\hline Flower-22 & 17.7 & 17.7 & 17.7 & 44.3 & 42.5 & 43.4 \\
\hline Flower-32 & 18.8 & 18.7 & 18.7 & 49.9 & 48.1 & 49.0 \\
\hline Flower-36 & 17.1 & 17.1 & 17.1 & 46.5 & 45.9 & 46.2 \\
\hline Brantley & 13.8 & 14.2 & 14.0 & 36.2 & 36.0 & 36.1 \\
\hline Wilson & 13.0 & 13.4 & 13.2 & 31.7 & 31.4 & 31.6 \\
\hline $\operatorname{LSD}\left(\% 5_{\mathrm{B}}\right)$ & 1.89 & 1.39 & 1.10 & 6.42 & 2.53 & 3.35 \\
\hline $\operatorname{LSD}\left(\% 5_{\mathrm{AxB}}\right)$ & NS & 1.97 & 2.19 & NS & 3.58 & 6.70 \\
\hline
\end{tabular}

The pod number per plant values of peanut varieties varied between 13.0-26.4 pods plant ${ }^{-1}$ in 2015 and 13.427.0 pods plant ${ }^{-1}$ in 2016. The differences between the varieties were found statistically significant for the pod number in both years. The reason of these differences between the varieties for the pod numbers originated from their genotypic background. Hassan et al. (2005) reported that significant differences for pod number per plant among peanut cultivars were attributed due to variation of the genotypes. The highest pod number per plant value was obtained from Osmaniye-2005 (26.4 and 27.0 pods plant $^{-}$ $\left.{ }^{1}\right)$ and the lowest from Wilson (13.0 and 13.4 pods plant $^{-1}$ ) in 2015 and 2016. According to a two-year average, the pod number per plant was varied between 13.2 and 26.7 pods plant ${ }^{-1}$. Gulluoglu et al. (2017) reported that the pod number per plant of the peanut varieties was varied between 22.44-52.40 pods plant ${ }^{-1}$ in main cropped conditions. Similar results were reported by some other researchers (Calıskan et al., 2008; Rahmianna et al., 2009; Canavar and Kaynak, 2013; Kaba et al., 2014 and
Gulluoglu et al., 2016b). Interaction between the harvesting times and varieties for the pod number per plant was not statistically significant in 2015 , but it was significant in 2016.

The differences between the harvesting times and peanut varieties were statistically significant for pod weight per plant in 2015, 2016 andin a two-year average. The pod weight per plant values varied between 39.3-57.5 $\mathrm{g} \mathrm{plant}^{-1}$ in 2015 , between $40.5-55.9 \mathrm{~g} \mathrm{plant}^{-1}$ in 2016 and between $39.9-56.7 \mathrm{~g}$ plant $^{-1}$ in a two-year average. By delaying the harvesting time from 149 DAS to 170 DAS, pod weight per plant was increased (Table 2). Gulluoglu et al. (2016a) reported that the pod weight was increased when the harvesting date was delayed from 148 DAP to 180 DAP. Pod formation and pod filling period was continually increased at the longer growing period. For this reason, the pod weight was increased when the harvesting date was delayed. 
The pod weight per plant in peanut varieties varied between $31.7-75.8 \mathrm{~g} \mathrm{plant}^{-1}$ in 2015 , between $31.4-73.7 \mathrm{~g}$ plant $^{-1}$ in 2016 and $31.6-74.7 \mathrm{~g} \mathrm{plant}^{-1}$ in a two-year average. According to a two-year average,the highest pod weight was obtained from Sultan $\left(74.7 \mathrm{~g} \mathrm{plant}^{-1}\right)$ and the lowest from Wilson (31.6 $\left.\mathrm{g} \mathrm{plant}^{-1}\right)$. The differences for pod weight per plant among peanut cultivars were attributed due to variation of the genotypes. Gulluoglu et al. (2017) indicated that the pod weight per plant of peanut varieties were ranges from $40.5 \mathrm{~g} \mathrm{plant}^{-1}$ to $95.55 \mathrm{~g}_{\text {plant }}{ }^{-1}$ in main cropped growing conditions.Interaction between the harvesting times and varieties for the pod weight per plant was not statistically significant in 2015, but significant in 2016 and in a two-year average. Rahmianna et al. (2009), Canavar and Kaynak (2013), Kaba et al. (2014) and Gulluoglu et al. (2016a) were found similar results.

\section{Seed weight and maturity index}

The differences between the harvesting times and peanut varieties were statistically significant for 100 -seed weight. The 100-seed weight varied between 120.3-129.3 $\mathrm{g}$ in 2015, between 118.6-127.0 $\mathrm{g}$ in 2016 and 122.5-128.2 $\mathrm{g}$ in a two-year average (Table 3 ).

Table 3. Effects of harvesting times on 100-seed weight and maturity index values of peanut varieties

\begin{tabular}{|c|c|c|c|c|c|c|}
\hline \multirow{2}{*}{ Treatments } & \multicolumn{3}{|c|}{ 100-seed weight $(\mathrm{g})$} & \multicolumn{3}{|c|}{ Maturity index (\%) } \\
\hline & 2015 & 2016 & 2015-2016 & 2015 & 2016 & 2015-2016 \\
\hline \multicolumn{7}{|c|}{ Harvesting times (A) } \\
\hline 149 DAS & 120.3 & 118.6 & 119.5 & 59.0 & 57.6 & 58.3 \\
\hline $156 \mathrm{DAS}$ & 123.7 & 121.3 & 122.5 & 60.8 & 59.7 & 60.2 \\
\hline 163 DAS & 127.0 & 124.7 & 125.9 & 63.0 & 62.9 & 63.0 \\
\hline 170 DAS & 129.3 & 127.0 & 128.2 & 65.6 & 65.0 & 65.3 \\
\hline $\operatorname{LSD}\left(\% 5_{\mathrm{A}}\right)$ & 2.84 & 2.39 & 5.74 & 0.95 & 1.28 & 1.41 \\
\hline \multicolumn{7}{|l|}{ Varieties (B) } \\
\hline Halisbey & 136.1 & 135.4 & 135.7 & 55.4 & 54.6 & 55.0 \\
\hline Sultan & 135.3 & 131.8 & 133.6 & 56.7 & 55.5 & 56.1 \\
\hline Arioglu-2003 & 109.1 & 107.1 & 108.1 & 61.1 & 59.9 & 60.5 \\
\hline Osmaniye-2005 & 132.2 & 130.9 & 131.5 & 56.1 & 56.3 & 56.2 \\
\hline $\mathrm{NC}-7$ & 121.8 & 119.7 & 120.8 & 67.5 & 66.5 & 67.0 \\
\hline Batem-5025 & 130.8 & 127.9 & 129.4 & 59.0 & 57.9 & 58.4 \\
\hline Flower-22 & 120.9 & 121.0 & 121.0 & 66.3 & 64.9 & 65.6 \\
\hline Flower-32 & 114.3 & 112.3 & 113.3 & 68.7 & 67.6 & 68.2 \\
\hline Flower-36 & 138.6 & 135.8 & 137.2 & 68.4 & 67.7 & 68.0 \\
\hline Brantley & 125.2 & 121.0 & 123.1 & 65.0 & 64.5 & 64.8 \\
\hline Wilson & 111.7 & 109.3 & 110.5 & 58.7 & 58.7 & 58.7 \\
\hline $\operatorname{LSD}\left(\% 5_{\mathrm{B}}\right)$ & 4.71 & 5.28 & 3.17 & 1.58 & 1.21 & 0.99 \\
\hline $\operatorname{LSD}\left(\% 5_{\mathrm{AxB}}\right)$ & NS & NS & NS & NS & NS & NS \\
\hline
\end{tabular}

According to-two year average, by delaying the harvesting time from 149 DAS to 170 DAS, 100-seed weight was increase from $119.5 \mathrm{~g}$ to $128.2 \mathrm{~g}$. When the harvesting time was delayed, the pod filling period increased. For this reason, the 100 -seed weight was increased when the harvesting time delayed. Talwar et al. (1999) indicated that the higher temperatures affect the reproductive growth adversely by increasing flower abortion and decreasing seed size. Knauft et al. (1986), Canavar and Kaynak (2013) and Gulluoglu et al. (2016a) reported that 100 -seed weight was increased when the harvesting time was delayed.

The highest 100-seed weight was obtained from Flower-36 (138.6 g and $135.8 \mathrm{~g})$ and the lowest from Arioglu-2003 (109.1 g and 107.1 g) in both years. The differences for 100 -seed weight among peanut cultivars were attributed due to variation of the genotypes. Interaction between the harvesting times and varieties for the 100 -seed weight was not statistically significant.

It can be seen in Table 3, the differences between the harvesting times and peanut varieties were significant for maturity index. The maturity index value varied between $59.0-65.6 \%$ in 2015 , between $57.6-65.0 \%$ in 2016 and $58.3-65.3 \%$ in a two-year average. The maturity index was significantly increased when the harvesting time was delayed from 149 DAS to 170 DAS in both years. Peanut has indeterminate growth habit and the plants produce flowers and pods as a long timeduring the growing period. It can be seen in Table 3, the varieties showed an increasing trend in the maturity index as harvesting time delayed.

The maturity index of the peanut varieties varied between $55.4-68.7 \%, 54.6-67.7 \%$ and $55.0-68.2 \%$, in 2015, 2016 and two years average, respectively.The maturity index of varieties was affected by the harvesting times. The maturity index value was increased when the harvesting delayed. The highest maturity index value was obtained from Flower-32 (68.2\%) and the lowest from Halisbey (55.0\%) varieties in a two-year average. Peanut varieties have different growing period. The maturity index value was lower in late varieties than early varieties in early harvesting. The differences between the varieties for the maturity index value originated from their 
genotypic back ground and growing period (Arioglu et al., 2017a). Interaction between the harvesting times and varieties for the maturity index value was not statistically significant. Similar result was found by Young and Mason (1972), Kaba et al. (2014) and Gulluoglu et al. (2016a).

\section{Shelling percentage and pod yield}

The average data belonging to shelling percentage and pod yield data of peanut varieties at different harvesting times has been presented in Table 4 .

The shelling percentage of peanut varieties was ranged from $69.1 \%$ to $71.5 \%$ in 2015 and from $67.8 \%$ to $70.8 \%$ in
2016 at different harvesting times (Table 4). The differences between the harvesting times and peanut varieties were statistically significant for shelling percentage in 2015, 2016 and two years average. When the harvesting time was delayed, the pod filling period extended and the pods fully matured. For this reason, the shelling percentage was increased when the harvesting time delayed. Shelling percentage was higher at each subsequent harvesting date. Overall the shelling percentage increased from $68.5 \%$ for the first harvesting date (149 DAS) to $68.5 \%$ for the last harvesting date (170 DAS) in a two-year average.

Table 4. Effects of harvesting times on shelling percentage and pod yield data of peanut varieties

\begin{tabular}{|c|c|c|c|c|c|c|}
\hline \multirow{2}{*}{ Treatments } & \multicolumn{3}{|c|}{ Shelling percentage (\%) } & \multicolumn{3}{|c|}{ Pod yield (kgha $\left.{ }^{-1}\right)$} \\
\hline & 2015 & 2016 & 2015-2016 & 2015 & 2016 & 2015-2016 \\
\hline \multicolumn{7}{|c|}{ Harvesting times (A) } \\
\hline $149 \mathrm{DAS}$ & 69.1 & 67.8 & 68.5 & 4231 & 4138 & 4185 \\
\hline 156 DAS & 69.9 & 68.9 & 69.4 & 4764 & 4534 & 4649 \\
\hline 163 DAS & 70.8 & 69.9 & 70.4 & 5353 & 5010 & 5181 \\
\hline 170 DAS & 71.5 & 70.8 & 71.2 & 5873 & 5490 & 5682 \\
\hline $\operatorname{LSD}\left(\% 5_{\mathrm{A}}\right)$ & 1.05 & 0.55 & 1.85 & 360.5 & 22.1 & 971.2 \\
\hline \multicolumn{7}{|l|}{ Varieties (B) } \\
\hline Halisbey & 65.4 & 64.8 & 65.1 & 7818 & 7412 & 7615 \\
\hline Sultan & 66.4 & 65.3 & 65.9 & 7553 & 7144 & 7348 \\
\hline Arioglu-2003 & 69.8 & 68.7 & 69.3 & 4745 & 4543 & 4644 \\
\hline Osmaniye-2005 & 68.0 & 67.5 & 67.8 & 7121 & 6916 & 7018 \\
\hline $\mathrm{NC}-7$ & 73.6 & 72.3 & 73.0 & 3304 & 3212 & 3258 \\
\hline Batem-5025 & 73.0 & 71.9 & 72.4 & 4011 & 3749 & 3880 \\
\hline Flower-22 & 74.0 & 72.4 & 73.2 & 4463 & 4216 & 4340 \\
\hline Flower-32 & 72.6 & 71.8 & 72.2 & 5024 & 4819 & 4922 \\
\hline Flower-36 & 72.4 & 71.0 & 71.7 & 4831 & 4520 & 4676 \\
\hline Brantley & 67.5 & 66.5 & 67.0 & 3595 & 3211 & 3403 \\
\hline Wilson & 71.2 & 70.6 & 70.8 & 3140 & 2984 & 3062 \\
\hline $\operatorname{LSD}\left(\% 5_{\mathrm{B}}\right)$ & 1.74 & 1.04 & 0.96 & 597.8 & 257.0 & 314.4 \\
\hline $\operatorname{LSD}\left(\% 5_{\mathrm{AxB}}\right)$ & NS & NS & NS & 1195.7 & 363.5 & 628.8 \\
\hline
\end{tabular}

The highest shelling percentage was obtained from Flower-22 $(74.0 \%$ and $72.4 \%)$ and the lowest from Halisbey $(65.4 \%$ and $64.8 \%)$ in both years. For a two-year average, the similar results were obtained. The differences between the varieties for the shelling percentage value originated from their genotypic background. Interaction between the harvesting times and varieties for the shelling percentage value was not significant. Similar results reported by Court et al. (1984), Knauft et al. (1986), Sattayarak (1997), Canavar and Kaynak (2013), Gulluoglu et al. (2016a), Gulluoglu et al. (2017) and Arioglu et al. (2017a).

The pod yield value varied between 4231-5873 $\mathrm{kgha}^{-1}$ in 2015 , between $4138-5490 \mathrm{kgha}^{-1}$ in 2016 and between 4185-5682 $\mathrm{kgha}^{-1}$ in a two-year average (Table 4). The differences between the harvesting times were statistically significant for pod yield per hectare in both years. The pod yield was increased when the harvesting time delayed. The highest pod yield was obtained from the peanut harvested at 170 DAS. According to a two-year average, the pod yield was increased $35.8 \%$ when the harvesting time delayed from 149 DAS to 170 DAS.

Pod number and pod weight per plant, shelling percentage and 100-seed weight are the very important agronomic characteristics for the pod yield. As it can be seen in Table 2,3 and 4 the data belonging to these characteristics were found higher in late harvesting than early harvesting. Park and Oh (1992) found that the pod yield was positively correlated to pod number, matured seed percent and 100-seed weight. Rahmianna et al. (2009) found out that harvesting times significantly affected weight of pods, well filled seeds, and shriveled seeds. A 10-day harvest delay resulted in $14.3 \%$ yield increases. Court et al. (1984) indicated that the pod yield increased $(48.2 \%)$ when the harvest delayed from 2 September to 12 October. Wright and Porter (1991) and Kaba et al. (2014) further indicated that harvesting peanut too early can reduced yield by $15 \%$ and economic value by $21 \%$. Gulluoglu et al. (2016a) reported that, the pod yield was increased $31.0 \%$ when the harvesting time delayed from 148 DAP to 180 DAP. Similar results were 
supported by findings of Knauft et al. (1986), Sattayarak (1997), Lu et al. (1997), Parasad et al. (2000), Rahmianna et al. (2009) and Canavar and Kaynak (2013).

The difference between the peanut varieties was statistically significant for the pod yield per hectare. Pod yield of the varieties ranged from 3140 to $7818 \mathrm{kgha}^{-1}$ in 2015 and from 2984 to $7412 \mathrm{kgha}^{-1}$ in 2016 in different peanut varieties. The highest pod yield was obtained from Halisbey (7818 $\mathrm{kgha}^{-1}$ and $7412 \mathrm{kgha}^{-1}$ ) and the lowest from Wilson (3140 $\mathrm{kgha}^{-1}$ and $2984 \mathrm{kgha}^{-1}$ ) varieties in both years (Table 4). Gulluoglu et al. (2017) indicated that the pod yield per hectare of peanut varieties were ranges from 3666 to $8796 \mathrm{kgha}^{-1}$ in main cropped growing conditions. Duncan et al. (1978) suggested that the length of the pod filling period and the rate of pod establishment is the best explain the variation in peanut yield.The differences between the varieties for the pod yield originated from their genotypic background. Interaction between the harvesting times and varieties for the pod yield were significant in both years.

\section{Protein and oil content}

It can be seen in Table 5, the differences between the harvesting times and peanut varieties were statistically significant for oil percentage in 2015, 2016 and in a twoyear average. The oil percentage values varied between $47.8-50.3 \%, 47.0-49.3 \%$ and $47.4-49.8 \%$ in 2015,2016 and two years average, respectively at different harvesting times. The oil percentage was increased when the harvesting time delayed.

Table 5. Effects of harvesting times on protein and oil content values of peanut varieties

\begin{tabular}{lcccccc}
\hline \multirow{2}{*}{ Treatments } & \multicolumn{3}{c}{ Protein content (\%) } & \multicolumn{3}{c}{ Oil content (\%) } \\
\cline { 2 - 7 } Harvesting times (A) & $\mathbf{2 0 1 5}$ & $\mathbf{2 0 1 6}$ & $\mathbf{2 0 1 5 - 2 0 1 6}$ & $\mathbf{2 0 1 5}$ & $\mathbf{2 0 1 6}$ & $\mathbf{2 0 1 5 - 2 0 1 6}$ \\
\hline 149 DAS & & & & & 47.4 & \\
156 DAS & 25.52 & 25.84 & 25.68 & 47.8 & 47.0 & 48.2 \\
163 DAS & 24.86 & 25.17 & 25.02 & 48.6 & 47.7 & 48.9 \\
170 DAS & 23.71 & 24.01 & 23.86 & 49.4 & 48.5 & 49.8 \\
LSD(\%5A) & 22.88 & 23.17 & 23.02 & 50.3 & 49.3 & 0.32 \\
Varieties (B) & 0.125 & 0.188 & 0.239 & 0.70 & 0.25 & \\
Halisbey & & & & & 49.0 \\
Sultan & 24.42 & 24.73 & 24.58 & 49.4 & 48.7 & 48.8 \\
Arioglu-2003 & 24.34 & 24.64 & 24.49 & 49.2 & 48.4 & 50.3 \\
Osmaniye-2005 & 25.07 & 25.39 & 25.23 & 50.7 & 49.8 & 50.5 \\
NC-7 & 25.24 & 25.56 & 25.40 & 51.0 & 49.9 & 46.9 \\
Batem-5025 & 23.37 & 23.66 & 23.52 & 47.3 & 46.4 & 49.8 \\
Flower-22 & 24.93 & 25.24 & 25.09 & 50.4 & 49.2 & 46.3 \\
Flower-32 & 23.07 & 23.36 & 23.21 & 46.6 & 46.0 & 46.0 \\
Flower-36 & 22.99 & 23.27 & 23.13 & 46.5 & 45.6 & 48.8 \\
Brantley & 24.36 & 24.67 & 24.52 & 49.2 & 48.4 & 47.4 \\
Wilson & 23.64 & 23.93 & 23.79 & 47.8 & 47.0 & 50.5 \\
LSD (\%5 $)$ & 25.26 & 25.57 & 25.41 & 51.1 & 50.0 & NS \\
LSD (\%5 & 0.208 & 0.200 & 0.103 & 1.17 & 0.44 & NS
\end{tabular}

Oil content is an important quality characteristic in peanut seed. The oil content of peanut seed influences by genotypic variation, growing conditions and maturity. Court et al. (1984) reported that the oil content was $45.8 \%$ in 2 September it was increased to $47.8 \%$ in 12 October. Sattayarak (1997), Lu et al. (1997) and Canavar and Kaynak (2013) reported that oil content was increased by delaying the harvesting times.

The oil percentage values of the peanut varieties varied between $46.5-51.1 \%$ in 2015 , between $45.6-50.0 \%$ in 2016 and $46.0-50.5 \%$ in a two-year average. The highest oil percentage was obtained from Wilson $(51.1 \%$ and $50.0 \%)$ and the lowest from Flower-32 (46.5\% and $45.6 \%$ ) in both years (Table 5). Hassan et al. (2005), Yav et al. (2008), Isleib et al. (2008) and Gulluoglu et al. (2017) reported that the oil percentage of peanut kernel varies between 35 and $56 \%$ depending on genotype and growing conditions, and the oil content of peanut varieties influence by genotype, seed maturity, climatic conditions, geographical location, growing season and growing conditions.Interaction between the harvesting times and varieties for the oil percentage was significant. Similar results were reported by some other researchers (Court et al., 1984; Sattayarak, 1997; Lu et al., 1997; Canavar and Kaynak, 2013; Arioglu et al., 2017a and Arioglu et al., 2017b)

The protein percentage values varied between 22.88 $25.52 \%$ in 2015 , between $23.17-25.84 \%$ in 2016 and $23.02-25.68 \%$ in a two-year average at different harvesting times (Table 5).The differences between the harvesting times and peanut varieties were statistically significant for protein percentage in both years and in a two-year average. The protein percentage was decreased when the harvesting time delayed. According to a twoyear average, the protein percentage was decreased from $25.68 \%$ to $23.02 \%$ when the harvesting time was delayed 
from 149 DAS to 170 DAS (Table 5). Sarkees (2015) reported that protein percentage was decreased from $22.0 \%$ to $19.8 \%$ when the planting delayed from April 22 to June 3. Gulluoglu et al. (2016a) found that the protein percentage was decreased from 25.60 to $24.65 \%$ when the harvesting time delayed from 148 DAP to 188 DAP.

It can be seen in Table 5, the protein percentage of peanut varieties values varied between 22.99-25.26\%, $23.27-25.57 \%$ and $23.13-25.41 \%$ in 2015,2016 and two years average, respectively. The highest protein percentage was obtained from Wilson $(25.26 \%, 25.57 \%$ and $25.41 \%$ ) and the lowest from Flower-32 (22.99\%, $23.275 \%$ and $23.13 \%$ ) in both years and two years average at different harvesting times.
The protein content of peanut varieties is influence by genotype, seed maturity, climatic conditions, geographical location and growing season. Gulluoglu et al. (2017) reported that the protein percentage of peanut varieties varied between $24.38 \%$ and $28.29 \%$ in main crop growing season. Interaction between the harvesting times and varieties for the protein percentage was not significant in both years and two years average. These results are in agreement with the findings of Court et al. (1984), Sarkees (2015) and Arioglu et al. (2017a).

\section{Fatty acids composition}

The average data belonging to saturated (palmitic and stearic acids) and unsaturated (oleic and linoleic acids) values of peanut varieties at different harvesting times has been presented in Table 6 and 7 .

Table 6. Effects of harvesting times on palmitic and stearic acids content of peanut varieties

\begin{tabular}{|c|c|c|c|c|c|c|}
\hline \multirow{2}{*}{ Treatments } & \multicolumn{3}{|c|}{ Palmitic acid } & \multicolumn{3}{|c|}{ Stearic acid } \\
\hline & 2015 & 2016 & 2015-2016 & 2015 & 2016 & 2015-2016 \\
\hline \multicolumn{7}{|c|}{ Harvesting times (A) } \\
\hline 149 DAS & 10.16 & 10.22 & 10.19 & 3.23 & 3.29 & 3.26 \\
\hline 156 DAS & 9.81 & 9.93 & 9.87 & 3.34 & 3.40 & 3.37 \\
\hline 163 DAS & 9.46 & 9.69 & 9.58 & 3.50 & 3.54 & 3.52 \\
\hline 170 DAS & 9.15 & 9.45 & 9.30 & 3.73 & 3.70 & 3.72 \\
\hline $\operatorname{LSD}\left(\% 5_{\mathrm{A}}\right)$ & 0.651 & 0.081 & 1.008 & 0.039 & 0.062 & 0.145 \\
\hline \multicolumn{7}{|l|}{ Varieties (B) } \\
\hline Halisbey & 9.76 & 9.97 & 9.87 & 3.28 & 3.31 & 3.30 \\
\hline Sultan & 10.01 & 10.10 & 10.06 & 3.47 & 3.40 & 3.44 \\
\hline Arioglu-2003 & 10.14 & 10.25 & 10.20 & 3.12 & 3.17 & 3.15 \\
\hline Osmaniye-2005 & 10.30 & 10.48 & 10.39 & 2.80 & 2.84 & 2.82 \\
\hline $\mathrm{NC}-7$ & 8.77 & 8.51 & 8.64 & 3.32 & 3.39 & 3.36 \\
\hline Batem-5025 & 8.42 & 8.53 & 8.48 & 3.50 & 3.55 & 3.53 \\
\hline Flower-22 & 12.16 & 12.06 & 12.11 & 3.89 & 3.93 & 3.91 \\
\hline Flower-32 & 11.57 & 12.08 & 11.83 & 4.04 & 4.09 & 4.07 \\
\hline Flower-36 & 11.52 & 11.91 & 11.72 & 4.14 & 4.19 & 4.17 \\
\hline Brantley & 5.55 & 5.80 & 5.68 & 3.28 & 3.33 & 3.31 \\
\hline Wilson & 7.92 & 8.40 & 8.16 & 3.11 & 3.13 & 3.12 \\
\hline $\operatorname{LSD}\left(\% 5_{\mathrm{B}}\right)$ & 0.220 & 0.134 & 0.128 & 0.059 & 0.102 & 0.059 \\
\hline $\operatorname{LSD}\left(\% 5_{\mathrm{AxB}}\right)$ & 0.441 & 0.267 & 0.256 & 0.119 & NS & 0.117 \\
\hline
\end{tabular}

The major fatty acids components are oleic acid, linoleic acid, palmitic acid and stearic acid in peanut oil. Andersen and Gorbet (2002) and Chowdhury et al. (2015) reported that the amount of saturated and unsaturated fatty acids in peanut oil varies from $10.92 \%$ to $17.47 \%$ and from $81.13 \%$ to $94.81 \%$, respectively. How and Young (1983), Carrin and Carelli (2010), Gulluoglu et al. (2016a) and Gulluoglu et al. (2016b) indicated that the fatty acid composition of peanut seed oil varies depending on the genotype, seed maturity, climate conditions, growth location, and interaction between these factors.

Saturated Fatty acids (Palmitic and stearic acids) content

As it can be seen inTable 6, the differences between the harvesting times and peanut varieties were statistically significant for the palmitic acid and stearic acid percentage in 2015, 2016 and in a two-year average.
The palmitic acid percentages varied between 9.15$10.16 \%$ in $2015,9.45-10.22 \%$ in 2016 and $9.30-10.19 \%$ in a two-year average at different harvesting times. The palmitic acid percentage was decreased when the harvesting time was delayed. Gulluoglu et al. (2016a) found out that palmitic acid content was decreased when the harvesting time delayed. Court et al. (1984), Knauft et al. (1986), Raheja et al. (1987), Hassan et al. (2005), Escobedo et al. (2015), Chowdhury et al. (2015) and Golukcu et al. (2016) were found similar results.

The palmitic acid percentage of peanut varieties varied between $5.68-12.11 \%$ in a two-year average. According to a two-year average, the highest palmatic acid percentage $(12.11 \%)$ was found in Flower-22 cultivar compared with rest of the cultivars. The lowest percentage of palmitic acid $(5.68 \%)$ was found in Brantley varieties (Table $6)$.The saturated fatty acids content in peanut oil were 
strongly influenced by genotype (Isleib et al., 2008). Gulluoglu et al. (2016b) indicated that the palmitic acid percentage of peanut varieties varied between 8.49$12.80 \%$ in main crop growing conditions. Significant differences for palmitic acid among cultivars are attributable to the genetic makeup and place of their origin (Hassan et al., 2005). The interaction between the harvesting time and varieties was significant in both years and two years average.

The stearic acid percentages varied between 3.23$3.73 \%, 3.29-3.70 \%$ and $3.26-3.72 \%$ in 2015, 2016 and in a two-year average, respectively (Table 6) at different harvesting times. The stearic acid percentage was increased when the harvesting time delayed.Young et al. (1972), Knauft et al. (1986) and Gulluoglu et al. (2016a) pointed outthat digging delays tended to give peanut oil with higher stearic acid content and the stearic acid content was increased when the harvesting time delayed.

The highest stearic acid percentage was obtained from Flower-36 (4.14\%, $4.19 \%$ and $4.17 \%)$ and the lowest from Osmaniye-2005 $(2.80 \%, 2.84 \%$ and $2.82 \%)$ varieties in both years and two years average at different harvesting times (Table 6). Gulluoglu et al. (2016b) indicated that the stearic acid percentage of peanut varieties varied between $8.49-12.80 \%$ in main crop growing conditions in Mediterranean region. The interaction between the harvesting time and varieties was significant in 2015 and two years average, but was not significant in 2016. These results are in agreement with the findings of Young et al. (1972), Brown et al. (1975), Knauft et al. (1986), Raheja et al. (1987), Chowdhury et al. (2015) and Golukcu et al. (2016).

\section{Unsaturated fatty acids (Oleic and linoleic acids) content}

Peanut oil is rich in oleic and linoleic acids. Oleic acid content in peanut genotypes can vary from $21 \%$ to $85 \%$ and linoleic acid from $2 \%$ to $43 \%$. In this research, the oleic acid percentage varied from $52.83 \%$ to $56.05 \%$ in 2015 , from $54.54-58.71 \%$ in 2016 and $53.69-57.38 \%$ in a two-year average (Table 7).The differences between the harvesting times were significant for the oleic acids percentage in both years and in a two-year average. According to a two-year average, while the oleic acid percentage was $53.69 \%$ at the harvesting 149 DAS, it increased up to $57.38 \%$ at the harvesting 170 DAS. As the harvesting time was delayed, the oleic acid percentage increased. Andersen and Gorbet (2002) and Gulluoglu et al. (2016a) reported that, seed maturity can also influence the fatty acid composition of peanut. Young et al. (1972) and Knauft et al. (1986) pointed out that digging delays tended to give peanut oil with higher oleic acid and less linoleic acid. Gulluoglu et al. (2016a) indicated that the oleic acid percentage was increased when the harvesting times delayed. Bovi (1982), Raheja et al. (1987) and Onemli (2012) reported that there was a negative correlation between oleic acid and linoleic acid content.

Table 7. Effects of harvesting times on oleic and linoleic acids content of peanut varieties

\begin{tabular}{|c|c|c|c|c|c|c|}
\hline \multirow{2}{*}{ Treatments } & \multicolumn{3}{|c|}{ Oleic acid (\%) } & \multicolumn{3}{|c|}{ Linoleic acid (\%) } \\
\hline & 2015 & 2016 & 2015-2016 & 2015 & 2016 & $2015-2016$ \\
\hline \multicolumn{7}{|c|}{ Harvesting times (A) } \\
\hline 149 DAS & 52.83 & 54.54 & 53.69 & 24.44 & 23.01 & 23.73 \\
\hline 156 DAS & 53.97 & 56.01 & 54.99 & 23.42 & 21.79 & 22.61 \\
\hline 163 DAS & 55.08 & 57.38 & 56.23 & 22.65 & 21.22 & 21.94 \\
\hline 170 DAS & 56.05 & 58.71 & 57.38 & 21.94 & 19.53 & 20.74 \\
\hline $\operatorname{LSD}\left(\% 5_{\mathrm{A}}\right)$ & 0.399 & 0.715 & 1.143 & 0.215 & 0.097 & 0.394 \\
\hline \multicolumn{7}{|l|}{ Varieties (B) } \\
\hline Halisbey & 53.69 & 54.39 & 54.04 & 23.66 & 23.19 & 23.43 \\
\hline Sultan & 53.71 & 53.77 & 53.74 & 24.62 & 24.38 & 24.50 \\
\hline Arioglu-2003 & 52.41 & 53.85 & 53.13 & 25.09 & 24.64 & 24.87 \\
\hline Osmaniye-2005 & 51.53 & 52.11 & 51.82 & 26.69 & 26.14 & $26 . .42$ \\
\hline $\mathrm{NC}-7$ & 59.77 & 63.01 & 61.39 & 17.79 & 17.28 & 17.54 \\
\hline Batem-5025 & 59.79 & 62.99 & 61.39 & 17.29 & 16.75 & 17.02 \\
\hline Flower-22 & 46.12 & 47.56 & 46.84 & 29.48 & 26.67 & 28.08 \\
\hline Flower-32 & 43.55 & 44.13 & 43.84 & 32.06 & 32.04 & 32.05 \\
\hline Flower-36 & 46.10 & 47.00 & 46.55 & 30.00 & 29.63 & 29.82 \\
\hline Brantley & 79.21 & 80.91 & 80.06 & 2.19 & 2.17 & 2.18 \\
\hline Wilson & 53.43 & 63.56 & 58.50 & 25.39 & 12.38 & 18.89 \\
\hline $\operatorname{LSD}\left(\% 5_{\mathrm{B}}\right)$ & 0.341 & 1.185 & 0.612 & 0.381 & 0.160 & 0.205 \\
\hline $\operatorname{LSD}\left(\% 5_{\mathrm{AxB}}\right)$ & 0.682 & 2.371 & 1.224 & 0.762 & 0.321 & 0.410 \\
\hline
\end{tabular}

The oleic acid percentage of peanut varieties varied between $43.55-79.21 \%$ in 2015 , between $44.13-80.91 \%$ in 2016 and $43.84-80.06 \%$ in a two-year average. The differences between the varieties for the oleic acid percentage were significant in both years and two years average. As it can be seen in Table 7, the highest oleic acid percentage was obtained from Brantley (79.21\%, $80.91 \%$ and $80.06 \%$ ) and the lowest from Flower-32 $(43.55 \%, 44.13 \%$ and $43.84 \%)$ varieties in both years and two years average. The fatty acids composition of Virginia 
type peanut cultivars varies $56.4-60.3 \%$ oleic and 24.2$26.8 \%$ linoleic acids (Brown et al., 1975). Gulluoglu et al. (2016b) indicated that the oleic acid percentage of peanut varieties varied between $39.80-81.13 \%$ in main crop growing conditions in Mediterranean region. The interaction between the harvesting time and varieties for the oleic acid content was significant in 2015, 2016 and in a two-year average. The results are corresponded well with the findings of Knauft et al. (1986), Dwivedi et al. (1996), Andersen and Gorbet (2002), Yav et al. (2008), Onemli (2012), Chaiyadee et al. (2013), Mzimbiri et al. (2014), Chowdhury et al. (2015), Golukcu et al. (2016) and Gulluoglu et al. (2016a).

The linoleic acid percentage varied from $21.94 \%$ to $24.44 \%$ in 2015 and from $19.53 \%$ to $23.01 \%$ in 2016 at different harvesting times. However, the linoleic acid percentage was decreased from $23.73 \%$ to $20.74 \%$ when the harvesting time was delayed from 149 DAP to 170 DAP in a two-year average (Table 7). The differences between the varieties for the linoleic acid percentage were significant in both years and two years average. As the harvesting time was delayed, the linoleic acid percentage decreased substantially. In general, oleic acid increases and linoleic acid decreases with seed maturity. Bovi (1982) Raheja et al. (1987) and Onemli (2012) reported that there was a negative correlation between oleic acid and linoleic acid. Gulluoglu et al. (2016a) found out that the linoleic acid percentage was decreased from 26.78 to $24.65 \%$ when the harvesting times delayed from 148 to 188 DAP.

The differences between the peanut varieties for the linoleic acid were significant in 2915, 2016 and in a twoyear average. The linoleic acid percentage of peanut varieties varied between $2.19-32.06 \%$ in 2015 , between 2.17-32.04\% in 2016 and between $2.18-32.05 \%$ in a twoyear average (Table 7). According to a two-year average, the highest linoleic acid percentage was obtained from Flower-32 (32.05\%) and the lowest from Brantley $(2.18 \%)$ varieties at different harvesting times. Andersen and Gorbet (2002) reported that linoleic acid content in peanut genotypes varied 2 to $43 \%$ and they reported that seed maturity can also influence the fatty acid composition of peanut. Bovi (1982), Raheja et al. (1987) and Onemli (2012) reported that there was a negative correlation between oleic acid and linoleic acid. Gulluoglu et al. (2016b) indicated that the linoleic acid percentage of peanut varieties varied between $1.73-36.38 \%$ in main crop growing conditions in Mediterranean region. The interaction between the harvesting time and varieties for the linoleic acid content was significant in 2015, 2016 and in a two-year average. Young et al. (1972), Knauft et al. (1986), Raheja et al. (1987), Hinds, (1995), Isleib et al. (2008), Onemli (2012), Chowdhury et al. (2015) and Golukcu et al. (2016) was found similar results.

\section{CONCLUSION}

Some agronomic and quality characteristics of peanut are influenced by genotype and environmental conditions during the growing season. Peanut has indeterminate growth habit and the plants produced many flowers during the growing period, but only $15-20 \%$ of flowers produced mature pods. Pod production continually increased with growth period, but harvested yield reached a peak and then declined due to increased field losses at delayed the harvesting date. Pod number and pod weight per plant, shelling percentage, maturity index, 100-seed weight and pod yield per hectare were increased when the harvesting times delayed. For this reason, it is very important cultural practice to determine the optimum harvesting time in peanut production.

Oil content and fatty acid composition are important quality characteristics in peanut seed and these factors influence by genotype, growing conditions and maturity. The major fatty acids components are oleic acid, linoleic acid, palmitic acid and stearic acid in peanut oil. The amount of saturated and unsaturated fatty acids in peanut oil varies from $10.92 \%$ to $17.47 \%$ and from $81.13 \%$ to $94.81 \%$, respectively. In this study, the oil content, stearic acid and oleic acid percentage were increased by delaying the harvesting times, but protein content, palmitic acid and linoleic acid percentage were decreased.The oil and fatty acids content of peanut varieties were found differ at the harvesting times.

\section{LITERATURE CITED}

Andersen, P.C. and D.W. Gorbet. 2002. Influence of year and planting date on fatty acid chemistry of high oleic acid and normal peanut genotypes. J. Agric. Food Chem. 50:12981305

Anonymous. 2015. FAO Production Year Book (www.fao.org)

Anonymous. 2017. The meteorological data for Adana. The Turkish State Meteorological Service Adana Regional Directorship, 2015, 2016 and long term.

AOAC. 2010. Official methods of analysis of the association of analytical chemists. $18^{\text {th }}$ Edition, Washington, D.C. USA

Arioglu, H., C. Kurt, H. Bakal, B.Onat,L. Gulluoglu and N.S. Sinan. 2013. The effects of pix (Mepiquat-chloride) application in different gowing stages on pod yield and some agonomic characters of peanut. Turkish Journal of Field Crops 18(2):260-267

Arioglu H.H., L. Gulluoglu and H. Bakal. 2017a. The effect of harvesting times on yield and some agronomic characteristics of peanut varieties grown in main cropped condition in Mediterranean Region (Turkey). Second International Balkan Agriculture Congress, Congress Book, p.180-187, Tekirdağ, Turkey

Arioglu H.H., L. Gulluoglu, H. Bakal, C. Kurt and B. Onat. 2017b. The effect of harvesting times on oil and fatty acid composition of peanut varieties grown in main cropped condition in Cukurova region (Mediterranean Area) in Turkey. $3^{\text {rd }}$ International Symposium for Agriculture and Food-ISAF-2017, Book of Abstracts, p.107, Ohrid, Republic of Macedonia

Bovi, M.L.A. 1982. Genotypic and environmental effect on fatty acid composition, iodine value and oil content of peanut (Arachis hypogaea L.). Ph. D. Dissertation. University of Florida, p. 119.

Brown, D.F., M.C. Carl, F.M. Karl and G.D. James. 1975. Effect of variety, growing location and their interaction on the fatty acid composition of peanut. J. Food Sci. 40:1055-1060

Caliskan, S., M.E. Caliskan, M. Arslan and H. Arioglu. 2008. Effects of sowing date and growth duration on growth and 
yield of groundnut in a Mediterranean-type environment in Turkey. Field Crops Res. 105:131-140

Canavar, O and M.A. Kaynak. 2013. Determination of yield and yield components and seed quality of peanuts (Arachis hypogaea L.) at different harvest times. Int. J. of Agronomy and Plant Production 4(S):3791-3803

Carrin, M.E and A.A. Carelli. 2010. Peanut Oil: Compositional data. Eur. J. Lipid Sci. Technol. 112:967-707

Chaiyadee, S., S. Jogloy, P. Songsri, N. Singkham, N. Vorasoot, P. Sawatsitang, C.C. Holbrook and A. Patanothai. 2013. Soil moisture affects fatty acids and oil quality parameters in peanut Int. J. of Plant Production 7(1):81-96

Chamberlin, K.D., N.A. Barkley, B.L. Tillman, J.W. Dillwith, R Madden, M.E. Payton and R.S. Bennett. 2014. A comparison of methods used to determine the oleic/linoleic acid ratio in cultivated peanut (Arachis hypogaea L.) Agricultural Science 5(3):227-237.

Chowdhury, F.N., D. Hossain, M. Hosen and S. Rahman. 2015. Comparative study on chemical composition of five varieties of groundnut (Arachis hypogaeaL.). World j. of Agricultural Science 11(5)247-254

Court W.A., R.C. Roy and J.G. Hendel. 1984. Effect of harvest date on agronomic and chemical characteristics of Ontario peanuts. Canadian J. Plant Science 64:521-528

Duncan, W.G., D.E. McCloud, R.L. McGraw and K.J. Boote 1978. Physiological aspects of peanut yield improvement. Crop Science 18:1015-1020

Dwivedi, S.L., S.N. Nigam, R. Jambunathan, K.L. Sahrawat, G.V.S. Nagabhushanam and K. Raghunath. 1996. Effect of genotypes and environments on oil and oil quality parameters and their correlation in peanut (Arachis hypogaea L.). Peanut Science 20:84-89

Escobedo, R.V., P.H. Luna, I.J.C. Torres, A.O. Mopreno and M.C.R. Ramirez. 2015. Physicochemical properties and fatty acid profile of eight peanut varieties grown in Mexico. Journal of Food 13(2):300-304

Golukcu, M.,R. Toker, H. Tokgoz and A. Kadiroglu. 2016. Antalya koşullarında yetiştirilen bazı yerfistığı (Arachis hypogaea L.) çeşitlerinin yă içerikleri ve yă asidi bileşimleri. Gıda 41(1):31-36

Gulluoglu, L. 2011. Effects of growth regulator applications on pod yield and some agronomic characters of peanut in Mediterranean region. Turkish Journal of Field Crops 16(2): 210-214

Gulluoglu, L., H. Bakal, B. Onat, C.Kurt and H. Arioglu. 2016a. The effect of harvesting dates on yield and some agronomic and quality characteristics of peanut grown in Mediterranean Region (Turkey) Turkish Journal of Field Crops 21(2): 224 232

Gulluoglu, L., H. Bakal, B. Onat, A. El Sabaghand H. Arioglu. 2016b. Characterization of peanut (Arachis hypogaea L.) seed oil and fatty acids composition under different growing season under Mediterranean environment, Journal of Experimental Biology and Agricultural Sciences, DOI:http://dx.doi.org/10.18006/2016, 4(5S):564-571

Gulluoglu L., H. Bakal, B. Onat, C. Kurt and H. Arioglu. 2017. Comparison of agronomic and quality characteristics of some peanut (Arachis hypogaea L.) varieties grown as main and double crop in Mediterranean region. Turkish Journal of Field Crops 22(2): 166-177, DOI:10.17557/TJFC.356208

Hassan, F., A. Manaf and M. Ejaz. 2005. Determinants of oil and fatty acid accumulation in peanut. Int. J. of Agriculture and Biology 7(6): 895-899

Hinds, M.J. 1995. Fatty acid composition of Caribbean-grown peanuts (Arachis hypogaea L.) at three maturity stages. Food Chemistry 53: 7-14
How,J.S.L. and C.T. Young. 1983. Comparison of fatty acid content of imported peanuts. JAOCS 6(5): 945-947

Ishag, H.M. 2000. Phenotypic and yield response of irrigated groundnut cultivars in a hot environment. Exp. Agric. 36: 303-312.

Isleib, T.G., B.L. Tilman, H.E. Patte, T.H. Sanders, K.W. Hendrix and L.O. Dean. 2008. Genotype-by-environment interaction for seed composition traits of breeding lines in the uniform peanut performance test. Peanut Science 35: $130-138$

Jordan, D.L., S. Danesha, L.Carley, C. Dharmasri, B.S. Turner, R.L. Brandenburg and G.B. Michael. 2008. Peanut response to planting date and potential of canopy reflectance as an indicator of pod maturation. Agronomy Journal 100: 376380

Kaba, J.S., K. Ofori and F.K. Kumaga. 2014. Inter-relationships of yield and components of yield at different stages of maturity in three groundnut (Arachis hypogaea L.) varieties. International J. of Life Science Research 2(1): 43-48

Knauft, A., A.J. Norden and D.W. Gorbet. 1986. The effect of three digging dates on oil quality, yield, and grade of five peanut genotypes grown without leaf spot control. Peanut Science 13: 86-89

Lu, K.C., M.S. Yeh, K.H. Yang and H.S. Lu. 1997. Effects of genotype, population density and harvest date on yield and quality of peanut. J. of Agric. Res. China 46(2): 116-131

Mzimbiri, R., A.M. Shi, H. Liu and Q. Wang. 2014. A Review: peanut fatty acids determination using hyper spectroscopy imagine and its significance on food quality and safety. Food Science and Quality Management 28: 90-97

Onemli, F. 2012. Impact of climate changes on oil fatty acid composition of peanut (Arachis hypogaea L.) in three market classes. Chilean J. Agri. Res. 72(4): 383-488

Park, C.K and J.H. Oh. 1992. Effect of cultural practice and harvest time on yield components of peanut. Korean J. Crop Science 37(4): 347-354

Prasad, P.V., P.Q. Craufurd and R.J. Summerfield. 2000. Effect of high air and soil temperature on dry matter production, pod yield and yield component of peanut. Plant and Soil 222:231-239

Raheja, R.K., S.K. Battai, K.L. Ahuja, K.S. Labana and M. Singh. 1987. Comparison of oil content and fatty acid composition of peanut genotypes differing in growth habit. Plant Foods for Human Nutrition 37:103-108

Rahmianna, A.A., A. Taufiq and E. Yusnawan. 2009. Pod yield and kernel quality of peanut grown under two different irrigations and two harvest times. Indonesian $\mathrm{J}$. of Agriculture 2(2)103-109

Sarkees, N.A. 2015. Effect of sowing dates on development, seed yield and quality of some peanut (Arachis hypogaea L.) genotypes. Jordan J. of Agricultural Sciences 11(2):367-380

Sattayarak, S. 1997. Effects of harvesting dates on different characters and seed quality of peanut grown in Southern Thailand. http://agris.fao.org/agris-search/.do?recordID= TH2000000950

Talwar, H., S. Takeda, H. Yashima and S.T. Senboku. 1999. Growth and photosynthetic responses of groundnut genotypes to high temperature. Crop Sci. 39:460-466

Williams, E.J. and J.S. Drexler. 1981. A non-destructive method for determining peanut pod maturity. Peanut Sci. 8:124-141

Wright, F.S. and D.M. Porter. 1991. Early leaf spot of peanuts: effect of conservation tillage practices on disease development. Peanut Science 8: 72-75

Yav, A.S., A. Richard, A.K. Osei, A.D.H. Kofi, O.D. Seth and A. Adelaide. 2008. Chemical composition of groundnut, (Arachis hypogaea L.) landraces. African J. of Biotechnology 7(13): 2203-2208 
Young, C. T., M.E. Manson, R.S. Matlock and G.R. Waller. 1972. Effect of maturity on the fatty acid composition of eight varieties of peanut grown at Parkins, Oklahoma in 1968. JAOCS, 49:314-317

Young, C.T and M.E. Mason. 1972. Free arginine content of peanut (Arachis hypogaea L.) as a measure of seed maturity. Journal of Food Science 37:722-725
Young, C.Y and R.E. Worthington. 1974. Fatty acid composition of Spanish peanut oil as influenced by planting location, soil moisture conditions, variety and season. AOCS, 51:312-315

Young, J. H., N.K. Person, J.O. Donald and W.D. Mayfield. 1982. Harvesting, Curing and Energy Utilization, pp.458485. In H.E. Pattee and C. T. Young (Eds). Peanut Science and Technology, Amer. Peanut Res. Educ. Society Inc., Yoakum. TX, USA. 